\title{
Book Review: Philosophy and Vulnerability: Catherine Breillat, Joan Didion and Audre Lorde by Mathew R. McLennan, Bloomsbury Academic, 2019, ISBN: 9781350004153
}

\author{
Debra Bergoffen \\ dbergoff@gmu.edu
}

Keywords: vulnerability; subjectivity; mastery; pre-philosophical experience; the humanities; language

Philosophy and Vulnerability may be read as a twofold reclamation project. One, to save the idea of subjectivity from its neo-liberal contortions. Two, to save what McLennan calls disciplinary philosophy from its demise by 'taking it down a peg' (27) and by dispelling the idea that it is a remote, hermetic activity (14). McLennan does not directly accuse disciplinary philosophy of fostering a neo-liberal version of subjectivity. Rather he argues that unless disciplinary philosophy attends to the pre-philosophical, existential experience of vulnerability, an experience obfuscated by the concept of the autonomous, neo-liberal subject, it will be dismissed as irrelevant. Taking philosophy down a peg, McLennan argues that insofar as these pre-philosophical experiences are not by definition the domain of philosophy proper, philosophy must take its cue from such non-philosophical sources as film, art, literature, and poetry. By turning to Catherine Breillat's, Joan Didion's, and Audre Lorde's, pre-philosophical experiences of vulnerability, McLennan offers his book as a recipe for 'flesh[ing] out a definition of philosophy that incorporates vulnerability as a key component' (4).

McLennan never provides a clear definition or description of what he calls disciplinary philosophy. He does, however, give a detailed account of his idea of vulnerability. Vulnerability, according to McLennan, is 'the self-conscious mastery of one's being mastered' (9). It is a reaching beyond oneself by mastering the situation of finitude by overcoming one's limitations through one's limitations (9). This mastery is neither solipsistic nor solitary. It is exercised within the possibilities of one's situation, including one's dependency on others, and the accidents of good and bad luck (17). Though we have no way to affect our luck, we are, according to McLennan, responsible for the conditions that impact our lives and those of others. This responsibility, he argues, requires that we engage in a politics of vulnerability that ensures that people are not victimized by their circumstances (16-17).

The discussions of Breillat's, Didion's, and Lorde's pre-philosophical experiences of vulnerability follows and is framed by this account of vulnerability. They are intended to make the point that though vulnerability is a key component of subjectivity, how it is experienced cannot be predicted, for each of these women deal with their confrontation with vulnerability differently.

McLennan does an admirable job of providing an analysis of the wide range of scholarship each woman's work has attracted. His examination of their diverse situations and experiences 
of vulnerability attests to the ways that their lives can be important resources for philosophy and for the idea that vulnerability is a key subjective experience.

In terms of the book's declared project of refreshing philosophy by attending to pre-philosophical sources, however, something is off. By coming to these sources with an already worked out concept of vulnerability they are not given to us as equally adequate experiences of vulnerability but are judged as more or less valid according to the criteria of vulnerability established at the outset. Thus Breillat is seen as too solipsistic in her attempt to master her vulnerability. Didion falls short because she is too focused on preserving the past. Lorde, however, passes McLennan's test both for the fact that she is focused on the present and for her political activism.

The movement from Breillat to Didion to Lorde follows the pattern of the Enlightenment idea of progress. The failures of Breillat's self-directed and Didion's other-directed but pastoriented attempts to master vulnerability set the stage for Lorde's self-care, other-directed, present-focused successful mastery, where the experience of vulnerability leads to an engagement in what McLennan identifies as a politics of vulnerability. It may be that McLennan arrived at his concept of successfully mastered vulnerability by listening to the experiences of these women. If this is the case, I would have liked to have heard how they were his teachers. As it stands it is difficult to avoid the impression that rather than being refreshed by these (re) sources, philosophy is given the authority to judge them.

I am sympathetic to McLennan's focus on vulnerability and to much of his account of it, for example that it attunes us to our dependency on others, that it exposes the fallacy of the idea of the autonomous subject, and that it alerts us to the injustices of institutions that enclose certain people/peoples in marginal/exploitive situations. I also endorse his affirmation of the close relationship between philosophy and the other humanities.

I am, however, troubled by the language and metaphors that permeate the book. For example, McLennan characterizes philosophy as a militant activity. What exactly is militant about philosophy that, according to Aristotle, begins in wonder? Why suggest that philosophy is a combative, aggressive endeavor rather than a dialogical one? What sorts of truths are arrived at through militant activities? The language used to describe the experience of vulnerability also gives me pause. What does it mean to speak of mastering finitude through finitude? What is being mastered? Why? By speaking of philosophy as a militant activity, of vulnerability as the self-conscious mastery of one's being mastered, of the need to master finitude, McLennan reinforces the desire to master, control, and overcome characteristic of neo-liberal and other master-minded subjectivities. He leaves the vulnerable subject vulnerable to being undone by these desires.

If we have learned anything from feminist, neo-colonial and Critical Race Theorists' critiques of the philosophical cannon we understand that words and metaphors have sedimented histories. Their baggage matters. In this case, McLennan's language of mastery deflects us from experiencing our finitude and vulnerability as something to be embraced as the source of the desire for love and friendship rather than as something to be overcome. By asking us to transcend finitude through finitude, McLennan invokes the desire to control what it given and to direct it toward a specific goal. By ranking the experiences of vulnerability of Breillat, Didion, and Lorde, he turns us away from a philosophy that describes how our different situations give us multiple ways of living our vulnerability toward a prescriptive philosophy of the legitimate way to live it. The prescription is not that of the autonomous subject, but insofar as it inscribes vulnerability in the idea of the One (as Irigaray would say) it preserves the dangerous legacies of this subject's appeal to a single authoritative mode of subjectivity.

I direct these concerns to McLennan in the form of the following questions: Why did you choose these words and metaphors rather than others? What work do they do? Why establish 
a hierarchy of the experience of vulnerability? These questions are raised in the spirit of McLennan's other, non-militant account of philosophy as an activity that deepens questions rather than providing answers. It questions the relationship between these two accounts of philosophy (10). It pursues the question of how to put the matter of vulnerability at the forefront of the philosophical agenda and raises the question of how doing this ties the fate of philosophy to that of other disciplines in the humanities (154).

\section{Competing Interests}

The author has no competing interests to declare.

How to cite this article: Bergoffen, Debra. 2020. "Book Review: Philosophy and Vulnerability: Catherine Breillat, Joan Didion and Audre Lorde by Mathew R. McLennan, Bloomsbury Academic, 2019, ISBN: $9781350004153 . "$ Redescriptions: Political Thought, Conceptual History and Feminist Theory 23(2), pp. 170-172. DOl: https://doi.org/10.33134/rds.338

Submitted: 29 September 2020 Accepted: 29 September 2020 Published: 15 December 2020

Copyright: (c) 2020 The Author(s). This is an open-access article distributed under the terms of the Creative Commons Attribution 4.0 International License (CC-BY 4.0), which permits unrestricted use, distribution, and reproduction in any medium, provided the original author and source are credited. See http://creativecommons.org/licenses/by/4.0/. 